\title{
Diffusion Coefficient at Resonance Frequency as Applied to $n+/ p / p+$ Silicon Solar Cell Optimum Base Thickness Determination
}

\author{
Amadou Mar Ndiaye1, Sega Gueye1, Mame Faty Mbaye Fall2 ${ }^{1}$, Gora Diop ${ }^{1}$, Amadou Mamour Ba1,

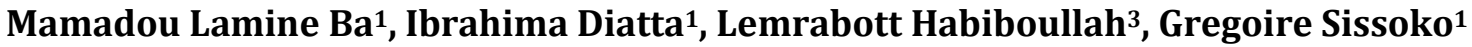 \\ ${ }^{1}$ Laboratory of Semiconductors and Solar Energy, Physics Department, Faculty of Science and Technology, University Cheikh \\ Anta Diop, Dakar, Senegal \\ ${ }^{2}$ Ecole Polytechnique de Thiès, Thiès, Sénégal \\ ${ }^{3}$ Département Génie Electrique, Ecole Supérieure Polytechnique de Nouakchott, Nouakchott, Mauritanie \\ Email: gsissoko@yahoo.com
}

How to cite this paper: Ndiaye, A.M., Gueye, S., Mbaye Fall, M.F., Diop, G., Ba, A.M., Ba, M.L., Diatta, I., Habiboullah, L. and Sissoko, G. (2020) Diffusion Coefficient at Resonance Frequency as Applied to $\mathrm{n}+/ \mathrm{p} / \mathrm{p}+$ Silicon Solar Cell Optimum Base Thickness Determination. Journal of Electromagnetic Analysis and Applications, 12, 145-158.

https://doi.org/10.4236/jemaa.2020.1210012

Received: October 1, 2020

Accepted: October 27, 2020

Published: October 30, 2020

Copyright ( 2020 by author(s) and Scientific Research Publishing Inc. This work is licensed under the Creative Commons Attribution International License (CC BY 4.0).

http://creativecommons.org/licenses/by/4.0/ (c) (i) Open Access

\begin{abstract}
The modelling and determination of the geometric parameters of a solar cell are important data, which influence the evaluation of its performance under specific operating conditions, as well as its industrial development for a low cost. In this work, an $n+/ p / p+$ crystalline silicon solar cell is studied under monochromatic illumination in modulation and placed in a constant magnetic field. The minority carriers' diffusion coefficient $(D(\omega, B)$, in the $(p)$ base leads to maximum values (Dmax) at resonance frequencies $(\omega r)$. These values are used in expressions of $\mathrm{AC}$ minority carriers recombination velocity $(\mathrm{Sb}(\mathrm{Dmax}, \mathrm{H}))$ in the rear of the base, to extract the optimum thickness while solar cell is subjected to these specific conditions. Optimum thickness modelling relationships, depending respectively on Dmax, $\omega r$ and $B$, are then established, and will be data for industrial development of low-cost solar cells for specific use.
\end{abstract}

\section{Keywords}

Silicon Solar Cell, Resonance Frequency, Magnetic Field, Recombination Velocity, Base Thickness

\section{Introduction}

Several phenomenological parameters of the base of the silicon solar cell, are the subject of theoretical and experimental investigations, for their determination. These are parameters such as: diffusion coefficient (D) [1], lifetime $(\tau)$ [2] [3], 
[4] [5], diffusion length (L) [6] [7] [8] [9], mobility $(\mu)$ [10] and recombination velocity [11] on surfaces of the different regions (front of the emitter [12] [13] [14], junction [15] [16] and rear side [8] [17] [18] [19] of the base) of the solar cell and grain joints recombination velocity (Sg) [20] [21] [22].

Geometric parameters' (different thicknesses and grain size) [23]-[29] optimization is important in studies aimed at improving the performance of the solar cell. In fact, they reduce both the distances to be covered by minority carriers before collection and the rate of recombination [30] [31]. Their determination is the subject of various theoretical and modelling studies and measurement techniques [3] [10] [32] [33] [34] [35] [36]

This work studies an $\mathrm{n}+/ \mathrm{p} / \mathrm{p}+$ silicon solar cell under monochromatic illumination $(\alpha(\lambda))$ [36] [37] in frequency modulation $(\omega)$ [24] [38], and placed under magnetic field $(B)$ [3] [10] [35]. The magneto-transport equation [10] in dynamic mode [39] of the excess minority carrier's density in the base of the solar cell is solved. Conditions at the limits of the base, i.e. at the junction and in the rear, are characterized respectively by recombination velocity ( $\mathrm{Sf}$ ) and ( $\mathrm{Sb}$ ) [16].

The ac photocurrent produced by the base, is studied at the resonance frequencies $(\omega r)$ imposed by specific magnetic field values to the minority carrier diffusion coefficient $D(\omega, B)$ [40] [41] [42] [43]. It is then analyzed at the high values of the junction recombination velocity (Sf) that impose the short circuit operating point to the solar cell. The expressions of the ac recombination velocity, are then deduced [41] [44] [45] [46] and their comparison by the graphic method [47] [48] [49] [50], leads to the determination of optimum thickness $(\operatorname{Hopt}(\operatorname{Dmax}))$ and modeled according to the frequency of resonance $(\omega r)$.

\section{Theoretical Model}

The structure of the $\mathrm{n}^{+}-\mathrm{p}-\mathrm{p}^{+}$silicon solar cell [18] [51] under front monochromatic illumination, in frequency modulation, is given by Figure 1 .

- The excess minority carriers' density $\delta(x, t)$ generated by an illumination in frequency modulation, in the base of the solar cell obeying to the continuity magneto-resistance equation, is given by:

$$
D(\omega, B) \times \frac{\partial^{2} \delta(x, t)}{\partial x^{2}}-\frac{\delta(x, t)}{\tau}=-G(x, \omega, t)+\frac{\partial \delta(x, t)}{\partial t}
$$

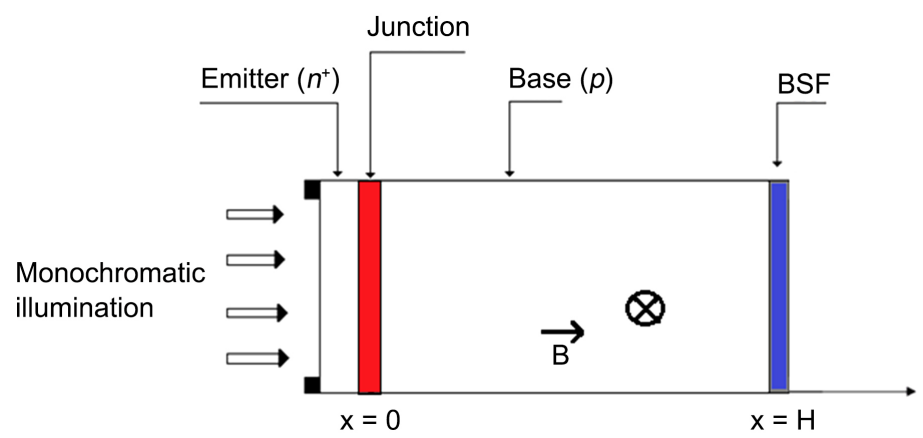

Figure 1. Structure of a front illuminated solar cell. 
The expression of the excess minority carriers' density is written, according to the space coordinates $(x)$ and the time $t$, as:

$$
\delta(x, t)=\delta(x) \cdot \mathrm{e}^{-j \omega t}
$$

\subsection{Generation Rate}

- AC carrier generation rate $G(x, t)$ is given by the relationship:

$$
G(x, t)=g(x) \cdot \mathrm{e}^{-j \omega t}
$$

The steady state generation rate is expressed as:

$$
g(x)=\alpha(\lambda) \cdot I_{0}(\lambda) \cdot(1-R(\lambda)) \cdot \mathrm{e}^{-\alpha \cdot(\lambda) \cdot x}
$$

$I_{0}$ is the incident flux, while $R(\lambda)$ and $\alpha(\lambda)$ are respectively, the reflection and absorption coefficients in the silicon material

\subsection{Boundary Conditions and Solution}

By replacing Equations (2) and (3) in Equation (1), the continuity equation for the excess minority carriers' density in the base is reduced to the following relationship:

$$
\frac{\partial^{2} \delta(x, \omega)}{\partial x^{2}}-\frac{\delta(x, \omega)}{L^{2}(\omega ; B)}=-\frac{g(x)}{D(\omega, B)}
$$

$L(\omega, B)$ is the complex diffusion length, under magnetic field and frequency modulation, of excess minority carriers in the base given by:

$$
L(\omega, B)=\sqrt{\frac{D(\omega, B) \tau}{1+j \omega \tau}}
$$

$\tau$ is the excess minority carriers lifetime in the base.

The solution of Equation (5) is:

$$
\delta(x, \omega, B, \lambda)=A \cdot \cosh \left[\frac{x}{L(\omega, B)}\right]+B \cdot \sinh \left[\frac{x}{L(\omega, B)}\right]+K \cdot \mathrm{e}^{-\alpha \cdot x}
$$

With

$$
K=\frac{\alpha(\lambda) \cdot I_{0} \cdot(1-R(\lambda)) \cdot[L(\omega, B)]^{2}}{D(\omega, B)\left[L(\omega, B)^{2} \cdot \alpha(\lambda)^{2}-1\right]}
$$

and

$$
\left(L(\omega, B)^{2} \cdot \alpha(\lambda)^{2} \neq 1\right)
$$

Coefficients $A$ and $B$ are determined through the boundary conditions:

- At the junction $(x=0)$

$$
\left.D(\omega, B) \frac{\partial \delta(x, \omega, B, \lambda)}{\partial x}\right|_{x=0}=\left.S f \cdot \frac{\delta(x, \omega, B, \lambda)}{D(\omega, B)}\right|_{x=0}
$$

- On the back side in the base $(x=H)$ 


$$
\left.D(\omega, B) \frac{\partial \delta(x, \omega, B, \lambda)}{\partial x}\right|_{x=H}=-\left.S b \cdot \frac{\delta(x, \omega, B, \lambda)}{D(\omega, B)}\right|_{x=H}
$$

$S f$ and $S b$ are respectively the recombination velocities of the excess minority carriers at the junction and at the back surface. The recombination velocity $S f$ reflects the charge carrier velocity of passage at the junction, in order to participate in the photocurrent. It is then imposed by the external load which fixes the solar cell operating point [15]. It has an intrinsic component which represents the carrier losses associated with the shunt resistor in the solar cell electrical equivalent model [20] [44] [45] [46]. The excess minority carrier recombination velocity $S b$ on the back surface is associated with the presence of the $\mathrm{p}^{+}$layer which generates an electric field for throwing back the charge carrier toward the junction [8] [17] [18].

\section{Results of AC Back Surface Recombination and Optimum Base Thickness Determination at Ringing Frequency}

\subsection{AC Back Surface Recombination}

The representation of AC photocurrent density according to the junction recombination velocity of minority carriers shows that, for very large $S f$, a bearing sets up and corresponds to the AC short-circuit current density (Jphsc) [44] [45] [46]. So, in this junction recombination velocity interval, we can write [16]:

$$
\left.\frac{\partial J_{p h}(S f, S b, \omega, B, \lambda)}{\partial S f}\right|_{S f \geq 10^{5}{\mathrm{~cm} \cdot \mathrm{s}^{-1}}}=0
$$

The solution of Equation (12) leads to the expressions of AC recombination velocity in the rear surface [41] [44] [45] given by Equations (13) and (14):

$$
\begin{gathered}
S b 1(\omega, B)=-\frac{D(\omega, B)}{L(\omega, B)} \cdot \tanh \left(\frac{H}{L(\omega, B)}\right) \\
S b 2(\omega, B, \lambda)=\frac{D(\omega, B)}{L(\omega, B)} \cdot\left[\frac{\alpha(\lambda) \cdot L(\omega, B) \cdot\left(\exp (-\alpha(\lambda) \cdot H)-\cosh \left(\frac{H}{L(\omega, B)}\right)+\sinh \left(\frac{H}{L(\omega, B)}\right)\right)}{\exp (-\alpha(\lambda) \cdot H)-\cosh \left(\frac{H}{L(\omega, B)}\right)+\alpha(\lambda) \cdot L(\omega, B) \cdot \sinh \left(\frac{H}{L(\omega, B)}\right)}\right]
\end{gathered}
$$

\subsection{AC Diffusion Coefficient and Ringing Frequency}

Minority carrier diffusion coefficient is influenced by external conditions applied to solar cell. It expression is dependent of parameter such as, temperature [52], magnetic field [10], charged particles fluence and intensity of irradiation [53], and others combined external conditions [42] [54] [55]. For this case under study $D(\omega, B)$ is the complex diffusion coefficient of excess minority carrier in the base under magnetic field and frequency modulation. Its expression is given by the relationship [40] [41] [43]: 


$$
\begin{aligned}
& D(\omega, B) \\
& =D \cdot\left[\frac{\left(1+\tau^{2} \cdot\left(\omega_{c}^{2}+\omega^{2}\right)\right)}{4 \cdot \omega^{2} \cdot \tau^{2}+\left[1+\tau^{2}\left(\omega_{c}^{2}-\omega^{2}\right)\right]^{2}}-\frac{j \cdot \omega \cdot \tau \cdot\left(1-\tau^{2}\left(\omega_{c}^{2}-\omega\right)^{2}\right)}{4 \cdot \omega^{2} \cdot \tau^{2}+\left[1+\tau^{2}\left(\omega_{c}^{2}-\omega^{2}\right)\right]^{2}}\right]
\end{aligned}
$$

With

$$
\omega_{c}=\frac{q \cdot B}{m_{e}^{*}}
$$

is the cyclotron frequency, $m_{e}^{*}$ the electron mass, and $q$ the elementary charge.

The diffusion coefficient is plotted in Figure 2. It decreases with the modulation frequency for different magnetic field values. We observe the appearance of resonance peaks [41] [43] for intensities of the upper magnetic field $10^{-7}$ Tesla, giving the maximum diffusion coefficient (Dmax) value.

Two areas of very weak magnetic fields emerge in Figure 2, with semi-logarithmic scale of frequency:

- a first zone $\left(\omega<10^{4} \mathrm{rad} / \mathrm{s}\right)$ where the complex diffusion coefficient is virtually constant corresponding to the quasi-static regime, which ends at the point of the cut-off frequency [24];

- a second zone (from $10^{4} \mathrm{rad} / \mathrm{s}$ to $10^{8} \mathrm{rad} / \mathrm{s}$ ) where the complex diffusion coefficient decreases drastically with pulsation, marking the frequency dynamic regime, or excess minority carriers appear frozen, because of their low relaxation time.

The application of a magnetic field to the solar cell in this frequency region, reveals a third area where the amplitude of the complex diffusion coefficient produces a peak, at a given frequency called resonance frequency [43].

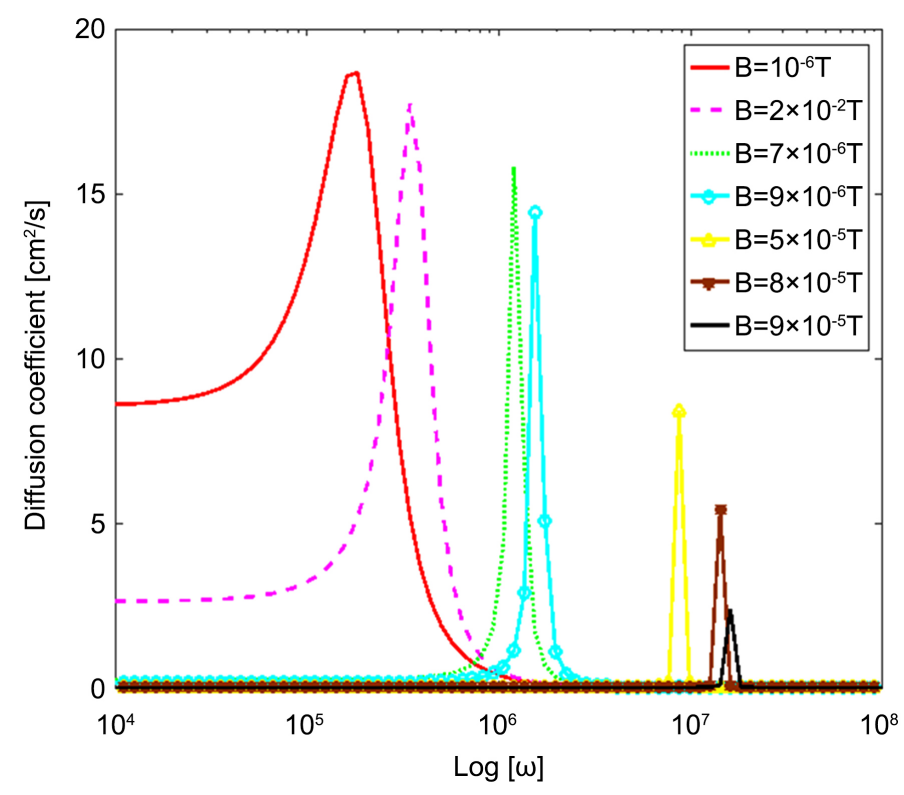

Figure 2. Diffusion coefficient versus frequencies for different magnetic field values $\left(D_{0}=35 \mathrm{~cm} ; \tau=10^{-5} \mathrm{~s}\right)$. 
This resonance phenomenon is obtained when the modulation frequency is equal to the cyclotron frequency [41] [43] (i.e. frequency of the electron in its orbit in the presence of a magnetic field).

Thus, the frequency of modulation with or without the application of a magnetic field to the solar cell, causes the reduction of the effective diffusion of excess minority carriers.

Also the study of the solar cell in frequency modulation, requires a choice of the values of the magnetic field (Table 1) for an optimal response through the diffusion coefficient (Dmax) to produce large photocurrent. Then such data will be used for the next calculations.

\subsection{Optimum Base Thickness}

Figure 3 gives the profile of the two expressions of AC back surface recombination velocity for different ringing frequencies inducing $D \max$ values, versus thickness of the base of the solar cell, under long wavelength $\left(\alpha(\lambda)=6.2 \mathrm{~cm}^{-1}\right)$. The technique [47] [48] [56] of the intercept point of the curves yields the optimum thickness of the base, and allow the establishment of data in Table 1.

As obtained in previous study [56] [57] [58] [59], the optimum thickness is an increasing straight line versus diffusion coefficient (Figure 4). Thus solar cell with large diffusion coefficient can be used for thick base solar cell manufacturing.

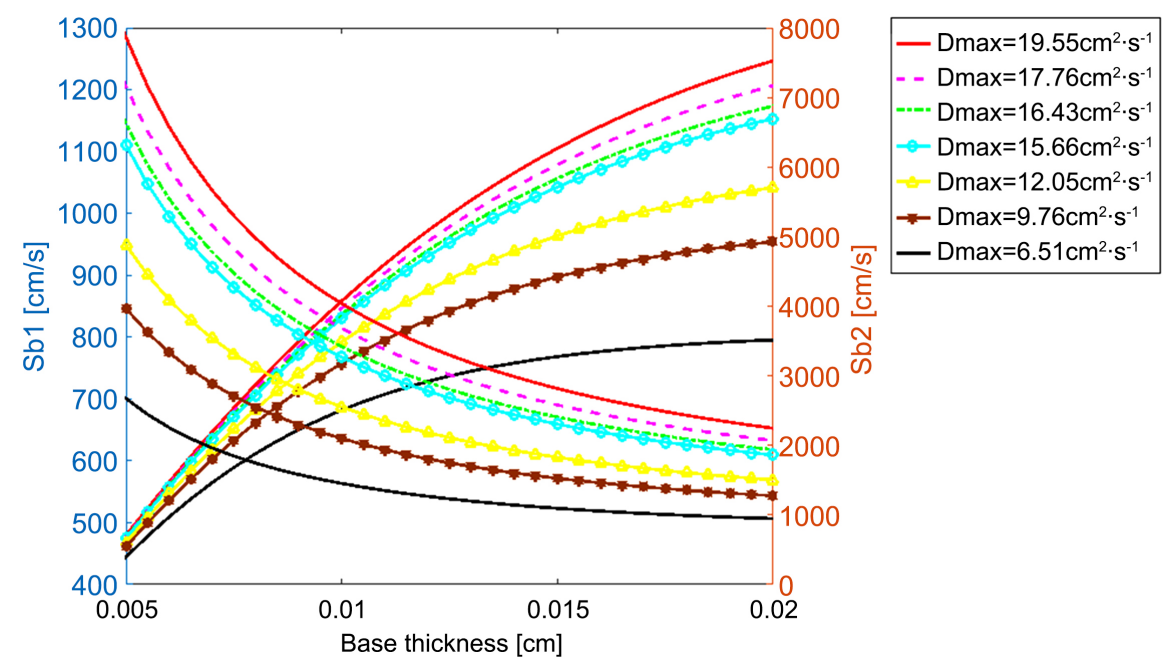

Figure 3. $\mathrm{Sb} 1$ and $\mathrm{Sb} 2$ versus depth in the base for different magnetic field values $\left(\mathrm{D}_{0}=\right.$ $35 \mathrm{~cm}^{2} / \mathrm{s} ; \alpha=6.2 \mathrm{~cm}^{-1}$ ).

Table 1. Ringing frequencies, maximum diffusion coefficient and diffusion length for given magnetic field.

\begin{tabular}{cccccccc}
\hline $\mathrm{B}(\mathrm{T})$ & $10^{-6}$ & $2 \times 10^{-6}$ & $7 \times 10^{-6}$ & $9 \times 10^{-6}$ & $5 \times 10^{-5}$ & $8 \times 10^{-5}$ & $9 \times 10^{-5}$ \\
$\omega r\left(\mathrm{rad} \cdot \mathrm{s}^{-1}\right)$ & $1.831 \times 10^{5}$ & $3.434 \times 10^{5}$ & $1.198 \times 10^{6}$ & $1.536 \times 10^{6}$ & $8.687 \times 10^{6}$ & $1.422 \times 10^{7}$ & $1.608 \times 10^{7}$ \\
$\operatorname{Dmax}\left(\mathrm{cm}^{2} / \mathrm{s}\right)$ & 19.55 & 17.76 & 16.43 & 15.66 & 12.05 & 9.76 & 6.51 \\
$\operatorname{Lmax}(\mathrm{cm})$ & 0.014 & 0.0133 & 0.0128 & 0.0125 & 0.0110 & 0.0099 & 0.0081 \\
Hop $(\mathrm{cm})$ & 0.01 & 0.0095 & 0.0092 & 0.0090 & 0.0085 & 0.0080 & 0.0075 \\
\hline
\end{tabular}


The relationship obtained is expressed as:

$$
\text { Hop }(\mathrm{cm})=1.8 \times 10^{-4} \times D \max \left(\mathrm{cm}^{2} / \mathrm{s}\right)+0.0063
$$

From obtained diffusion length in Table 1, base optimum thickness is represented in Figure 5.

The representation is also an increase strait line [50] expresses as:

$$
H o p(\mathrm{~cm})=0.39 \times L \max (\mathrm{cm})+0.0042
$$

Figure 6 and Figure 7, give the representation of the optimum thickness versus $(\omega r)$ and magnetic field $(B)$ respectively. The plots of Hopt, are similar, because of the ratio $\left(q / m_{e}^{*}\right)$ in Equation (6), then the effects of both the resonance frequency and the magnetic field impose thin thicknesses base.

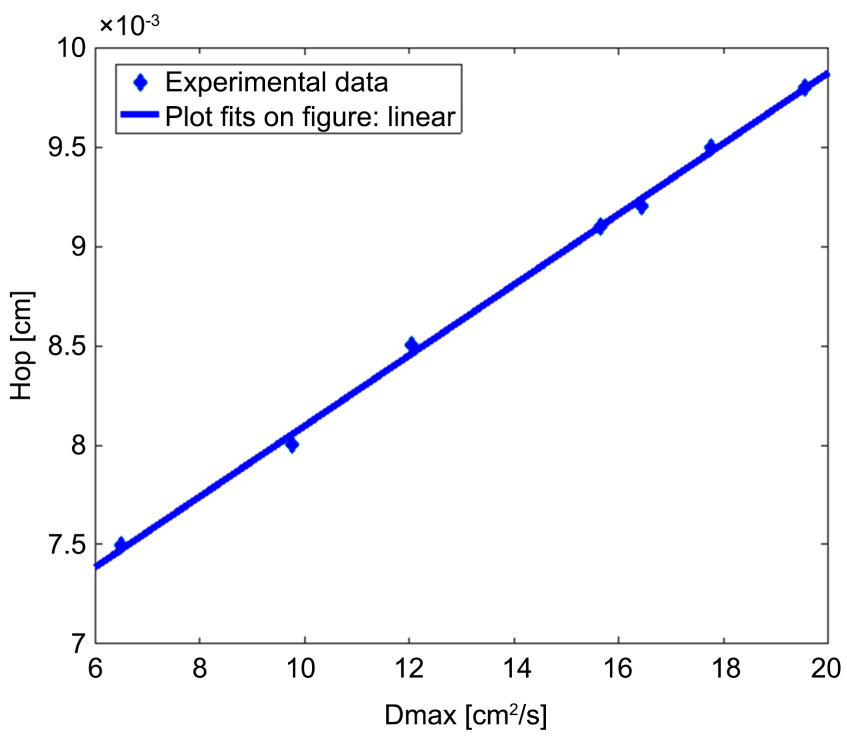

Figure 4. Optimum thickness of the base versus Dmax.

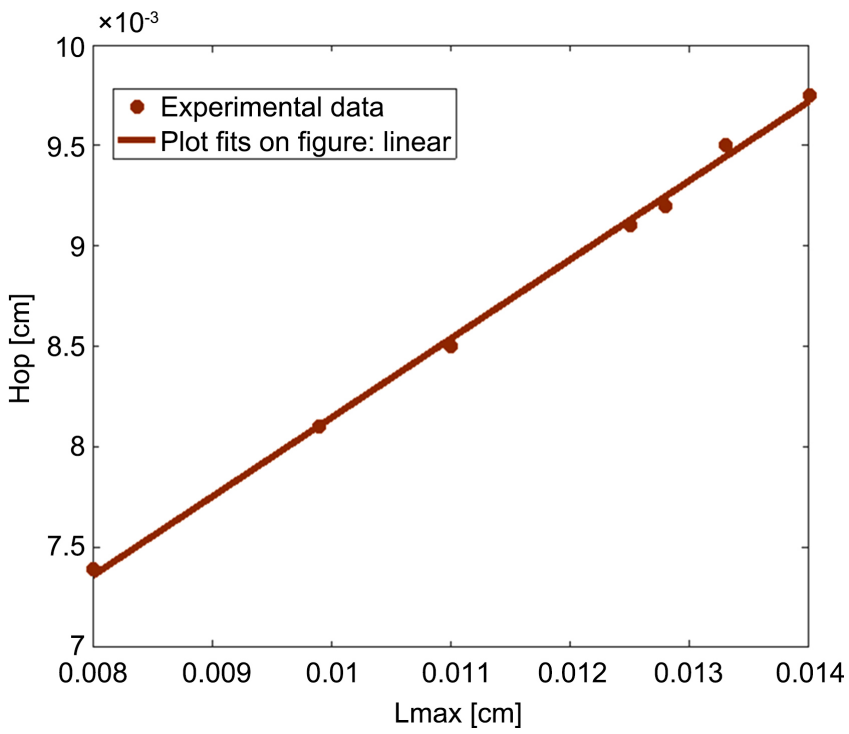

Figure 5. Lmax versus optimum thickness of the base. 


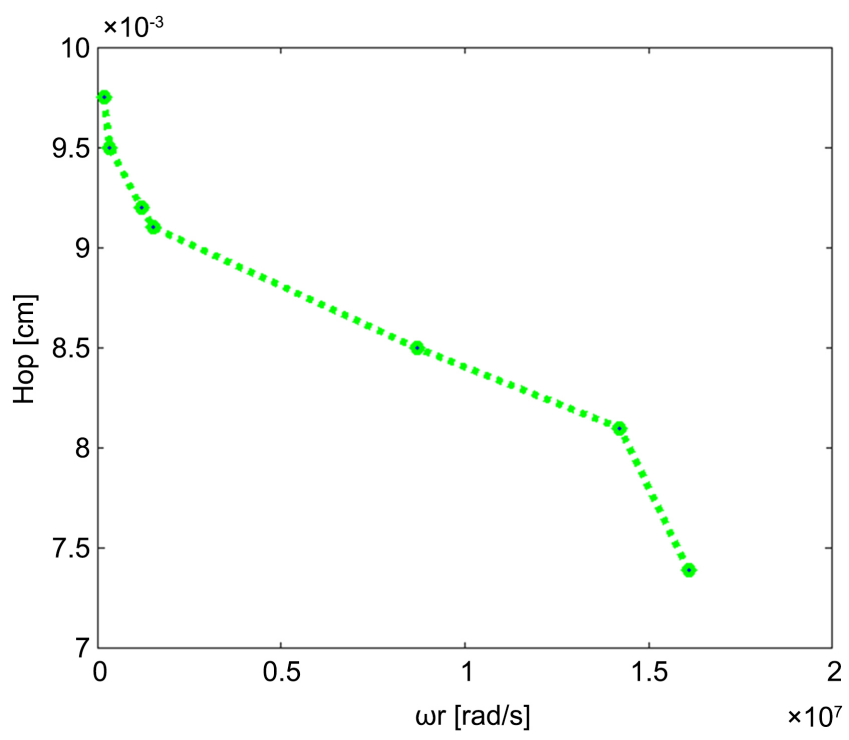

Figure 6. Optimum thickness of the base versus $\omega r$.

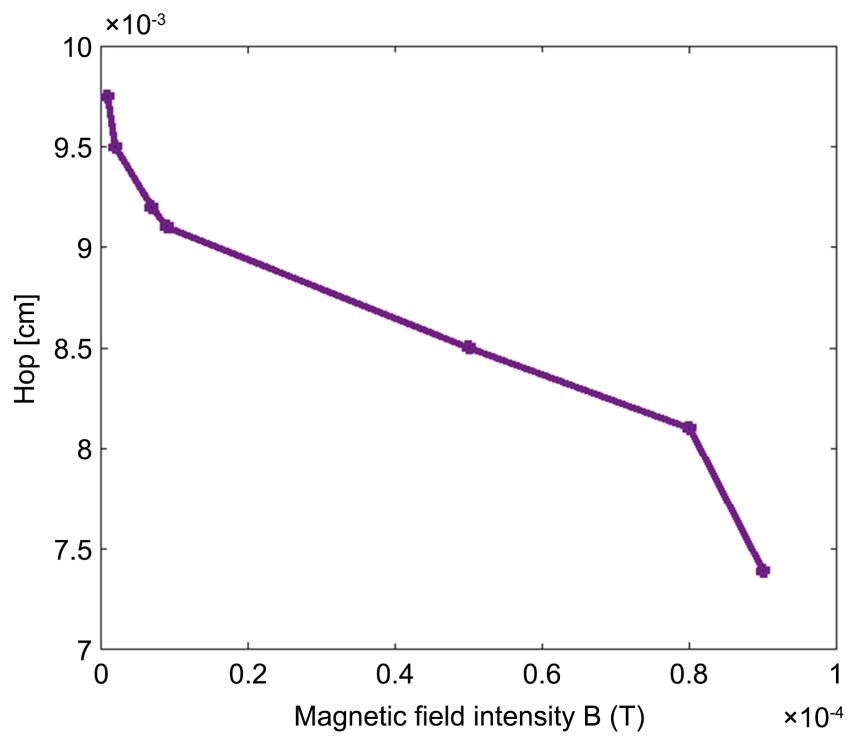

Figure 7. Optimum thickness of the base versus magnetic field.

\section{Discussions}

The technique of determining the optimum thickness of the base of the solar cell from the expressions of the recombination velocity in the rear face, was widely used and produced Hopt expressions according to the parameters of the experiment, including the magnetic field, temperature, irradiation flow of charged particles. The results obtained take into account the conditions of development of the solar cell (Doping rate) [60] and experimental. Thus the solar cell remained in static or dynamic frequency regime and with the possibility of variation of:

1) The parameters influencing the diffusion coefficient:

- by applying a magnetic field (B) [48], or irradiation by a flux ( $\phi p)$ of charged particles [61], temperature variation (T) [62] 
- by combining several external experience factors, above mentioned [50] [58] 2) The parameters influencing recombination velocity expressions, including:

- the spectral composition of light (monochromatic [49] [56] or polychromatic [63]) having a constant incident photons flux or in frequency modulation

- the mode of illumination that can be, perpendicular to the junction (by the front [64] or by the back side [49]) or parallel to the junction (Vertical Mutijunctions) [57] [62] [65]

These two types of parameters influence the technique of determining the optimum thickness of the base, taking into account the optoelectronic factors.

The different results showed a linear growth of the optimum thickness of the base with the diffusion coefficient of excess minority carriers, regardless of the experimental conditions [47] [48] [49] [50] [56] [57] [58] [62] [65].

\section{Conclusions}

In the case of our study, the variation in the frequency of illumination on the solar cell maintained in a magnetic field has also produced large thicknesses of the solar cell consistent with the large values of the diffusion coefficient (i.e. long diffusion length), corresponding to the frequency of resonance. The optimum thickness (Hopt), depending on parameters, such as, the magnetic field, temperature, the irradiation flow of charged particles, suffered a decrease, as in our study.

This study expands the results on the determination of the optimum thickness of the $(p)$ base of the silicon solar cell, allowing the best choices in the optimization of low-cost wafers in the industrial elaboration of the solar cell, for its adaptation to the conditions of use.

\section{Conflicts of Interest}

The authors declare no conflicts of interest regarding the publication of this paper.

\section{References}

[1] Rosling, M., Bleichner, H., Mundqvist, M. and Nordlander, E. (1992) A Novel Technique for the Simultaneous Measurement of Ambipolar Carrier Lifetime and Diffusion Coefficient in Silicon. Solid-State Electronics, 35, 1223-1227. https://doi.org/10.1016/0038-1101(92)90153-4

[2] Dhariwal, S.R. and Vasu, N.K. (1981) A Generalized Approach to Lifetime Measurement in pn Junction Solar Cells. Solid-State Electronics, 24, 915-927. https://doi.org/10.1016/0038-1101(81)90112-X

[3] Vardanyan, R.R., Kerst, U., Wawer, P., Nell, M.E. and Wagemann, H.G. (1998) Method for Measurement of All Recombination Parameters in the Base Region of Solar Cells. 2nd World Conference and Exhibition on Photovoltaic Solar Energy Conversion, Vienna, 191-193.

[4] Zondervan, A., Verhoef, L.A. and Lindholm, F.A. (1988) Measurement Circuits for Silicon-Diode and Solar Cells Lifetime and Surface Recombination Velocity by Electrical Short-Circuit Current Delay. IEEE Transactions on Electron Devices, 35, 
85-88. https://doi.org/10.1109/16.2419

[5] Lindholm, F.A., Liou, J.J., Neugroschel, A. and Jung, T.W. (1987) Determination of Lifetime and Surface Recombination Velocity of p-n Junction Solar Cells and Diodes by Observing Transients. IEEE Transactions on Electron Devices, 34, 277-283. https://doi.org/10.1109/T-ED.1987.22919

[6] Stokes, E.D. and Chu, T.L. (1977) Diffusion Lengths in Solar Cells from Short-Circuit Current Measurements. Applied Physics Letters, 30, 425-426. https://doi.org/10.1063/1.89433

[7] Jain, G.C., Singh, S.N. and Kotnala, R.K. (1983) Diffusion Length Determination in $\mathrm{n}^{+}-\mathrm{p}-\mathrm{p}^{+}$Structure Based Silicon Solar Cells from the Intensity Dependence of the Short-Circuit Current for Illumination from the $\mathrm{p}^{+}$Side. Solar Cells, 8, 239-248. https://doi.org/10.1016/0379-6787(83)90063-7

[8] Sissoko, G., Nanema, E., Correa, A., Adj, M., Ndiaye, A.L. and Diarra, M.N. (1998) Recombination Parameters Measurement in Double Sided Surface Field Solar Cell. Proceedings of World Renewable Energy Conference, Florence, 1856-1859.

[9] Sharma, S.K., Singh, S.N., Chakravarty, B.C. and Das, B.K. (1986) Determination of Minority-Carrier Diffusion Length in a p-Silicon Wafer by Photocurrent Generation Method. Journal of Applied Physics, 60, 3550-3552.

https://doi.org/10.1063/1.337610

[10] Betser, Y., Ritter, D., Bahir, G., Cohen, S. and Serling, J. (1995) Measurement of the Minority Carrier Mobility in the Base of Heterojunction Bipolar Transistors Using a Magneto Transport Method. Applied Physics Letters, 67, 1883-1884.

https://doi.org/10.1063/1.114364

[11] Patrick De Visschere Comment on G. J. REES (1986) Surface Recombination Velocity-A Useful Concept? Solid-State Electronics, 29, 1161-1165. https://doi.org/10.1016/0038-1101(86)90059-6

[12] Jain, S.C., Agarwal, S.K. and Harsh (1983) Importance of Emitter Recombination in Interpretation of Reverse Recovery Experiments at High Injections. Journal of Applied Physics, 54, 3618-3619. https://doi.org/10.1063/1.332400

[13] Ray, U.C. and Agarwal, S.K. (1988) Wavelength Dependence of Short-Circuit Current Decay in Solar Cells. Journal of Applied Physics, 63, 547-549. https://doi.org/10.1063/1.340084

[14] Del Alamo, J., Eguren, J. and Luque, A. (1980) Operating Limits of Al-Alloyed High-Low Junction for BSF Solar Cells. Solid-States-Electronics, 24, 415-420. https://doi.org/10.1016/0038-1101(81)90038-1

[15] Sissoko, G., Sivoththanam, S., Rodot, M. and Mialhe, P. (1992) Constant Illumination-Induced Open Circuit Voltage Decay (CIOCVD) Method, as Applied to High Efficiency Si Solar Cells for Bulk and Back Surface Characterization. 11 th European Photovoltaic Solar Energy Conference and Exhibition, Montreux, 12-16 October 1992, 352-354.

[16] Sissoko, G., Museruka, C., Corréa, A., Gaye, I. and Ndiaye, A.L. (1996) Light Spectral Effect on Recombination Parameters of Silicon Solar Cell. Renewable Energy, 3, 1487-1490.

[17] Joardar, K., Dondero, R.C. and Schroder, D.K. (1989) A Critical Analysis of the Small-Signal Voltage-Decay Technique for Minority-Carrier Lifetime Measurement in Solar Cells. Solid-State Electronics, 32, 479-483. https://doi.org/10.1016/0038-1101(89)90030-0

[18] Fossum, J.G. (1977) Physical Operation of Back-Surface-Field Silicon Solar Cells. IEEE Transactions on Electron Devices, 2, 322-325. 
https://doi.org/10.1109/T-ED.1977.18735

[19] Wang, C.H. and Neugroschel, A. (1991) Minority-Carrier Lifetime and Surface Recombination Velocity Measurement by Frequency-Domain Photoluminescence. IEEE Transactions on Electron Devices, 38, 2169-2180.

https://doi.org/10.1109/16.83745

[20] Diallo, H.L., Seïdou, A., Maiga, Wereme, A. and Sissoko, G. (2008) New Approach of Both Junction and Back Surface Recombination Velocities in a 3D Modelling Study of a Polycrystalline Silicon Solar Cell. The European Physical Journal Applied Physics, 42, 203-211. https://doi.org/10.1051/epjap:2008085

[21] Dugas, J. (1994) 3D Modelling of a Reverse Cell Made with Improved Multicrystalline Silicon Wafers. Solar Energy Materials and Solar Cells, 32, 71-88.

https://doi.org/10.1016/0927-0248(94)90257-7

[22] Donalato, C. (1994) Reciprocity Theorem for Charge Collection by a Surface with Finite Collection Velocity: Application to Grain Boundaries. Journal of Applied Physics, 76, 959-966. https://doi.org/10.1063/1.357774

[23] Van Steenwinkel, R., Carotta, M.C., Martinelli, G., Merli, M., Passari, L. and Palmeri, D. (1990) Lifetime Measurement in Solar Cells of Various Thicknesses and the Related Silicon Wafers. Solar Cells, 28, 287-292. https://doi.org/10.1016/0379-6787(90)90063-B

[24] Honma, N. and Munakata, C. (1987) Sample Thickness Dependence of Minority Carrier Lifetimes Measured Using an AC Photovoltaic Method. Japanese Journal of Applied Physics, 26, 2033-2036. https://doi.org/10.1143/JJAP.26.2033

[25] Demesmaeker, E., Symons, J., Nijs, J. and Mertens, R. (1991) The Influence of Surface Recombination on the Limiting Efficiency and Optimum Thickness of Silicon Solar Cells. 10th European Photovoltaic Solar Energy Conference, Lisbon, 8-12 April 1991, 66-67. https://doi.org/10.1007/978-94-011-3622-8_17

[26] Gueye, M., Diallo, H.L., Moustapha, A.K.M., Traore, Y., Diatta, I. and Sissoko, G. (2018) AC Recombination Velocity in a Lamella Silicon Solar Cell. World Journal of Condensed Matter Physics, 8, 185-196. https://doi.org/10.4236/wjcmp.2018.84013

[27] Traore, Y., Thiam, N., Thiame, M., Thiam, A., Lamine Ba, M., Diouf, M.S., Diatta, I., Mballo, O., Sow, E.H., Wade, M. and Sissoko, G. (2019) AC Recombination Velocity in the Back Surface of a Lamella Silicon Solar Cell under Temperature. Journal of Modern Physics, 10, 1235-1246. https://www.scirp.org/journal/jmp https://doi.org/10.4236/jmp.2019.1010082

[28] Diasse, O., Diao, A., Ly, I., Diouf, M.S., Diatta, I., Mane, R., Traore, Y. and Sissoko, G. (2018) Back Surface Recombination Velocity Modeling in White Biased Silicon Solar Cell under Steady State. Journal of Modern Physics, 9, 189-201. https://doi.org/10.4236/jmp.2018.92012

[29] Dieng, M., Seibou, B., Ibrahima, L.Y., Diouf, M.S., Wade, M. and Sissoko, G. (2017) Silicon Solar Cell Emitter Extended Space Charge Region Determination under Modulated Monochromatic Illumination by Using Gauss's Law. International Journal of Innovative Technology and Exploring Engineering, 6, 17-20.

[30] Terheiden, B., Terheiden, G., Hahn, P., et al. (2000) The Lamella Silicon Solar Cell. Proc. 16th European Photovoltaic Solar Energy Conference, Glasgow, 1-5 May 2000, 1377-1380.

[31] Gaubas, E. and Vanhellemont, J. (1996) A Simple Technique for the Separation of Bulk and Surface Recombination Parameters in Silicon. Journal of Applied Physics, 80, 6293-6974. https://doi.org/10.1063/1.363705

[32] Bordin, N., Kreinin, L. and Eisenberg, N. (2001) Determination of Recombination 
Parameters of Bifacial Silicon Cells with a Two Layer Step-Liked Effect Distribution in the Base Region. Proc. 17 th European PVSEC, Munich, 1495-1498.

[33] Jung, T.-W., Lindholm, F.A. and Neugroschel, A. (1984) Unifying View of Transient Responses for Determining Lifetime and Surface Recombination Velocity in Silicon Diodes and Back-Surface-Field Solar Cells, with Application to Experimental Short-Circuit-Current Decay. IEEE Transactions on Electron Devices, 31, 588-595. https://doi.org/10.1109/T-ED.1984.21573

[34] Gupta, S., Ahmed, F. and Garg, S. (1988) A Method for the Determination of the Material Parameters D, $\mathrm{L}_{0}, \mathrm{~S}$ and from Measured A.C. Short-Circuit Photocurrent. Solar Cells, 25, 61-72. https://doi.org/10.1016/0379-6787(88)90058-0

[35] Flohr, Th. and Helbig, R. (1989) Determination of Minority-Carrier Lifetime and Surface Recombination Velocity by Optical-Beam-Induced-Current Measurements at Different Light Wavelengths. Journal of Applied Physics, 66, 3060-3065. https://doi.org/10.1063/1.344161

[36] Saritas, M. and Mckell, H.D. (1988) Comparison of Minority Carrier Diffusion Length Measurements in Silicon by the Photoconductive Decay and Surface Photovoltage Methods. Journal of Applied Physics, 63, 4561-4567. https://doi.org/10.1063/1.340155

[37] Antilla, O.J. and Hahn, S.K. (1993) Study on Surface Photovoltage Measurement of Long Diffusion Length Silicon: Simulation Results. Journal of Applied Physics, 74, 558-569. https://doi.org/10.1063/1.355343

[38] Ly Diallo, H., Wade, M., Ly, I., et al. (2012). 1D Modeling of a Bifacial Silicon Solar Cell under Frequency Modulation, Monochromatic Illumination: Determination of the Equivalent Electrical Circuit Related to the Surface Recombination Velocity. Research Journal of Applied Sciences, Engineering and Technology, 4, 1672-1676. http://www.maxwell.org

[39] Bousse, L., Mostarshed, S. and Hafeman, D. (1994) Investigation of Carrier Transport through Silicon Wafers by Photocurrent Measurements. Journal of Applied Physics, 75, 4000-4008. https://doi.org/10.1063/1.356022

[40] Cardona, M. (1969) Solid State Physics. Supplement 11, Modulation Spectroscopy. Academic Press, New York.

[41] Dieng, A., Zerbo, I., Wade, M., Maiga, A.S. and Sissoko, G. (2011) Three-Dimensional Study of a Polycrystalline Silicon Solar Cell: The Influence of the Applied Magnetic Field on the Electrical Parameters. Semiconductor Science and Technology, 26, Article ID: 095023. https://doi.org/10.1088/0268-1242/26/9/095023

[42] Diouf, S., Ndiaye, M., Thiam, N., Traore, Y., Lamine Ba, M., Diatta, I., Diouf, M.S., Mballo, O., Thiam, A., Ly, I. and Sissoko, G. (2019) Influence of Temperature and Frequency on Minority Carrier Diffusion Coefficient in a Silicon Solar Cell under Magnetic Field. Energy and Power Engineering, 11, 355-361.

https://www.scirp.org/journal/epe https://doi.org/10.4236/epe.2019.1110023

[43] Diao, A., Thiam, N., Zoungrana, M., Sahin, G., Ndiaye, M. and Sissoko, G. (2014) Diffusion Coefficient in Silicon Solar Cell with Applied Magnetic Field and under Frequency: Electric Equivalent Circuits. World Journal of Condensed Matter Phys ics, 4, 84-92. https://doi.org/10.4236/wjcmp.2014.42013

[44] Zerbo, I., Barro, F.I., Mbow, B., Diao, A., Madougou, S., Zougmore, F. and Sissoko, G. (2004) Theoretical Study of Bifacial Silicon Solar Cell under Frequency Modulate white Light: Determination of Recombination Parameters. Proceedings of the 19th European Photovoltaic Solar Energy Conference, Paris, 7-11 June 2004, 258-261. 
[45] Ly, I., Zerbo, I., Wade, M., Ndiaye, M., Dieng, A., Diao, A., Thiam, N., Thiam, A., Dione, M.M., Barro, F.I., Maiga, A.S. and Sissoko, G. (2011) Bifacial Silicon Solar Cell under Frequency Modulation and Monochromatic Illumination: Recombination Velocities and Associated Equivalent Electrical Circuits. Proceedings of 26 th European Photovoltaic Solar Energy Conference and Exhibition, Hamburg, 298-301.

[46] Thiam, Nd., Diao, A., Ndiaye, M., Dieng, A., Thiam, A., Sarr, M., Maiga, A.S. and Sissoko, G. (2012) Electric Equivalent Models of Intrinsic Recombination Velocities of a Bifacial Silicon Solar Cell under Frequency Modulation and Magnetic Field Effect. Research Journal of Applied Sciences, Engineering and Technology, 4, 4646-4655. https://doi.org/10.19026/rjaset.5.4825

[47] Ndiaye, A., Gueye, S., Sow, O., Diop, G., Ba, A., Ba, M., Diatta, I., Habiboullah, L. and Sissoko, G. (2020) A.C. Recombination Velocity as Applied to Determine $\mathrm{n}+/ \mathrm{p} / \mathrm{p}+$ Silicon Solar Cell Base Optimum Thickness. Energy and Power Engineering, 12, 543-554.

[48] Diop, G., Gueye, S., Sow, O., Mamour, A., Lamine, M., Diatta, I. and Sissoko, G. (2020) Ac Composite Back Surface Recombination Velocity as Applied to $\mathrm{n}^{+} / \mathrm{p} / \mathrm{p}^{+}$ Silicon Solar Cell Optimum Thickness Base Determination. International Journal of Advanced Research, 8, 580-587. https://doi.org/10.21474/IJAR01/11695

[49] Dede, M.M.S., Ba, M.L., Ba, M.A., Ndiaye, M., Gueye, S., Sow, E.H., Diatta, I., Diop, M.S., Wade, M. and Sissoko, G. (2020) Back Surface Recombination Velocity Dependent of Absorption Coefficient as Applied to Determine Base Optimum Thickness of an $\mathrm{n}^{+} / \mathrm{p} / \mathrm{p}^{+}$Silicon Solar Cell. Energy and Power Engineering, 12, 445-458. https://www.scirp.org/journal/epe https://doi.org/10.4236/epe.2020.127027

[50] Faye, D., Gueye, S., Ndiaye, M., Ba, M.L., Diatta, I., Traore, Y., Diop, M.S., Diop, G., Diao, A. and Sissoko, G. (2020) Lamella Silicon Solar Cell under Both Temperature and Magnetic Field: Width Optimum Determination. Journal of Electromagnetic Analysis and Applications, 12, 43-55. https://doi.org/10.4236/jemaa.2020.124005 https://www.scirp.org/journal/paperinformation.aspx?paperid=99976

[51] Nam, L.Q., Rodot, M., Ghannam, M., Cppye, J., de Schepper, P. and Nijs, J. (1992) Solar Cells with 15.6\% Efficiency on Multicristalline Silicone, Using Impurity Gettering, Back Surface Field and Emitter Passivation. International Journal of Solar Energy, 11, 273-279. https://doi.org/10.1080/01425919208909745

[52] Kunst, M., Muller, G., Schmidt, R. and Wetzel, H. (1988) Surface and Volume Decay Processes in Semiconductors Studied by Contactless Transient Photoconductivity Measurements. Applied Physics, 46, 77-85. https://doi.org/10.1007/BF00615912

[53] Kraner, H.W. (1983) Radiation in Silicon Detectors. 2nd Pisa Meeting in Advanced Detectors, Grosseto, 3-7 June 1983, 1-8.

[54] Mane, R., Ly, I., Wade, M., Datta, I., Douf, M.S., Traore, Y., Ndiaye, M., Tamba, S. and Sissoko, G. (2017) Minority Carrier Diffusion Coefficient $D^{\star}(B, T)$ : Study in Temperature on a Silicon Solar Cell under Magnetic Field. Energy and Power Engineering, 9, 1-10. http://www.scirp.org/journal/epe https://doi.org/10.4236/epe.2017.91001

[55] Ndiaye, E.H., Sahin, G., Dieng, M., Thiam, A., Diallo, H.L., Ndiaye, M. and Sissoko, G. (2015) Study of the Intrinsic Recombination Velocity at the Junction of Silicon Solar Cell under Frequency Modulation and Radiation. Journal of Applied Mathematics and Physics, 3, 1522-1535. http://www.scirp.org/journal/jamp https://doi.org/10.4236/jamp.2015.311177

[56] Dede, M.M.S., Ndiaye, M., Gueye, S., Ba, M.L., Diatta, I., Diouf, M.S., Sow, E.H., Ba, A.M., Diop, M. and Sissoko, G. (2020) Optimum Base Thickness Determination 
Technique as Applied to $\mathrm{n} / \mathrm{p} / \mathrm{p}^{+}$Silicon Solar Cell under Short Wavelengths Monochromatic Illumination. International Journal of Innovation and Applied Studies, 29, 576-586. http://www.ijias.issr-journals.org

[57] Diop, G., Ba, H.Y., Thiam, N., Traore, Y., Dione, B., Ba, M.A., Diop, P., Diop, M.S., Mballo, O. and Sissoko, G. (2019) Base Thickness Optimization of a Vertical Series Junction Silicon Solar Cell under Magnetic Field by the Concept of Back Surface Recombination Velocity of Minority Carrier. ARPN Journal of Engineering and Applied Sciences, 14, 4078-4085.

[58] Mohamed, N.M.M.O., Sow, O., Gueye, S., Traore, Y., Diatta, I., Thiam, A., Ba, M.A., Mane, R., Ly, I. and Sissoko, G. (2019) Influence of Both Magnetic Field and Temperature on Silicon Solar Cell Base Optimum Thickness Determination. Journal of Modern Physics, 10, 1596-1605. https://www.scirp.org/journal/jmp https://doi.org/10.4236/jmp.2019.1013105

[59] Ely, M.M., Thiam, N., Ndiaye, M., Traore, Y., Mane, R., Sow, E., Mballo, O., Dieng, M.S., Sarr, C.T., Ly, I. and Sissoko, G. (2020) Surface Recombination Velocity Concept as Applied to Determinate Back Surface Illuminated Silicon Solar Cell Base Optimum Thickness, under Temperature and External Magnetic Field Effects Journal of Scientific and Engineering Research, 7, 69-77.

[60] Diop, M.S., Ba, H.Y., Thiam, N., Diatta, I., Traore, Y., Lamine Ba, M., Sow, E.H., Mballo, O. and Sissoko, G. (2019) Surface Recombination Concept as Applied to Determinate Silicon Solar Cell Base Optimum Thickness with Doping Level Effect. World Journal of Condensed Matter Physics, 9, 102-111. https://doi.org/10.4236/wjcmp.2019.94008

[61] Ba, M.L., Thiam, N., Thiame, M., Traore, Y., Diop, M.S., Ba, M., Sarr, C.T., Wade, M. and Sissoko, G. (2019) Base Thickness Optimization of a $\left(\mathrm{n}^{+}-\mathrm{p}-\mathrm{p}^{+}\right)$Silicon Solar Cell in Static Mode under Irradiation of Charged Particles. Journal of Electromagnetic Analysis and Applications, 11, 173-185. https://doi.org/10.4236/jemaa.2019.1110012

[62] Ndiaye, F.M., Ba, M.L., Ba, M.A., Diop, G., Diatta, I., Sow, E.H., Mballo, O. and Sissoko, G. (2020) Lamella Silicon Optimum Width Determination under Temperature. International Journal of Advanced Research, 8, 1409-1419.

https://doi.org/10.21474/IJAR01/11228

[63] Mballo, O., Seibou, B., Wade, M., Diouf, M.S., Ly, I., Tamba, S. and Sissoko, G. (2016) Influence of the Depth Base on the Electrical Parameters of a Parallel Vertical Junction Silicon Solar Cell under Polychromatic Illumination. International Journal of Electrical Engineering, 4, 6-16.

[64] Diallo, M.M., Seibou, B., Ba, H.Y., Zerbo, I. and Sissoko, G. (2014) One-Dimensional Study of a Bifacial Silicon Solar Cell Illuminated from the Front Surface by a Monochromatic Light under Frequency Modulation: Influence of Irradiation and Damage Coefficient. Current Trends in Technology and Sciences, 3, 416-421.

[65] Dia, O., El Moujtaba, M.A.O., Gueye, S., Ba, M.L., Diatta, I., Diop, G., Diouf, M.S. and Sissoko, G. (2020) Optimum Thickness Determination Technique as Applied to a Series Vertical Junction Silicon Solar Cell under Polychromatic Illumination: Effect of Irradiation. International Journal of Advanced Research, 8, 616-626. https://doi.org/10.21474/IJAR01/10967 